\title{
Ameloblastic Fibroma of Maxilla and Maxillary Sinus A Case Report
}

\author{
Mohammed Al-Bodbaij* and Christopher Iwu \\ Department of Oral and Maxillofacial Surgery, King Fahad Hospital-Hofuf, KSA
}

Submission: May 18, 2018; Published: June 21, 2018

*Corresponding author: Mohammed Al-Bodbaij, Department of Oral and Maxillofacial Surgery, King Fahad Hospital-Hofuf, KSA, Tel: +96635750000, E-mail: bodbaij@hotmail.com

\begin{abstract}
Ameloblastic fibroma (AF) is a rare mixed odontogenic tumor, It occurs mainly in young individuals with no sexual or racial predilection. It arises mainly in the mandible. The treatment of AF is controversial. Some authors recommend wide excision of the tumor, while others support enucleation or curettage initially with reserving modified block resection for recurrence. In this report, we present a case of ameloblastic fibroma of the maxilla and maxillary sinus which was treated by enucleation and curettage and has been followed up for more than two years without any evidence of residual tumor or recurrence.
\end{abstract}

\section{Introduction}

Ameloblastic fibroma (AF) and related lesions are defined by WHO as neoplasms composed of proliferating odontogenic epithelium embedded in a cellular ectomesnchymal tissue resembling dental papilla and with varying degrees of inductive change and dental hard tissue formation [1].

Ameloblastic fibroma is a rare mixed odontogenic tumor; accounts for $2.5 \%$ of odontogenic tumors [2,3]. It occurs primarily in young individuals $(70 \%$ of patients are younger than the age of 20 years at presentation). There is no sexual or racial predilection [4-6]. Ameloblastic fibroma arises in the mandible in most of the cases (about 80\%) with remainder arising in the maxilla $[4,5,7,8]$. Patients with ameloblastic fibroma usually complain of swelling of the jaw, failure of tooth eruption and /or pain $[2,4]$. Radiographically, AF appears radiolucent multilocular or unilocular cyst with difficulty in distinguishing it from simple ameloblastoma $[2,4,7]$.

\section{Case Report}

A 20 years old, married, Saudi female came to Oral \& Maxillofacial Surgery Clinic of King Fahad Hospital- Hofuf, Saudi Arabia, complaining of pain which has started since few weeks around pointing teeth which failed to erupt in addition to swelling of the left side of the face. Swelling started five years earlier with gradual increase in size.

\section{Medical History: Patient has no significant medical history.}

Extra-oral examination showed asymmetrical expansion of left malar region and cheek. There was no ocular involvement and no regional lymphoadenopathy. Intra- oral examination showed swelling of left maxilla; expanding palatally, mesially and anterolaterally obliterating the upper left buccal sulcus from tooth \# 23 to tooth \# 27 region. Swelling was bony hard on all surfaces except the alveolar surface which is cystic in consistency with pointing multiple odontomes. Plain radiographs (orthopantomogram \& occipitomental view) and Computerized Tomography (CT) showed well defined expansile mass within left maxilla and left maxillary sinus; with radiopaque dental tissues (odontomes) and displaced tooth \# 28 (Figure 1). The lesion caused deviation of nasal septum and there was no erosion of orbital floor or displacement of ocular contents (Figures $2 \& 3$ ).

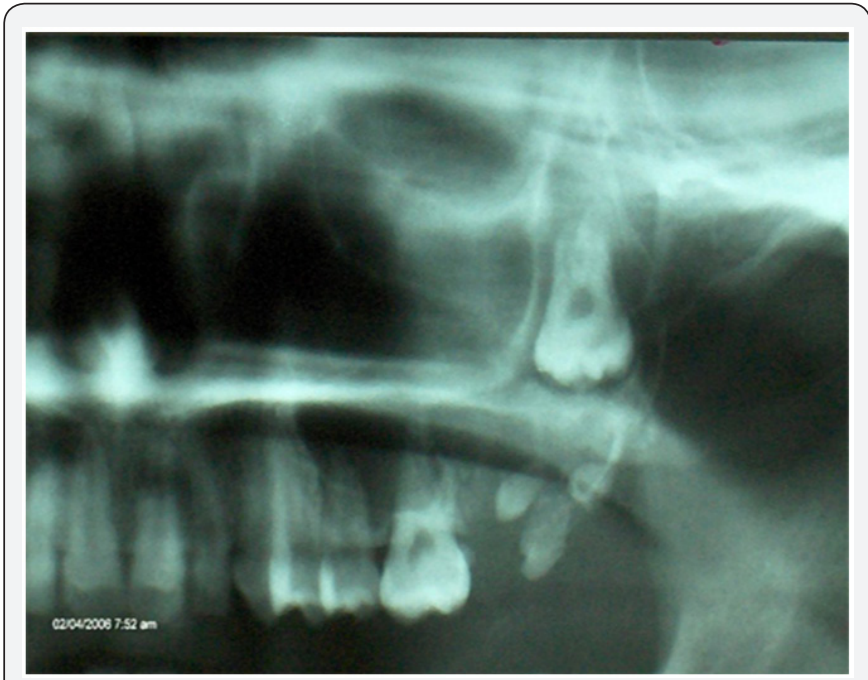

Figure 1: OPG radiograph showing an expansile mass displacing tooth \# 28 \& three radiopaque masses (odontomes). 


\section{Advances in Dentistry \& Oral Health}

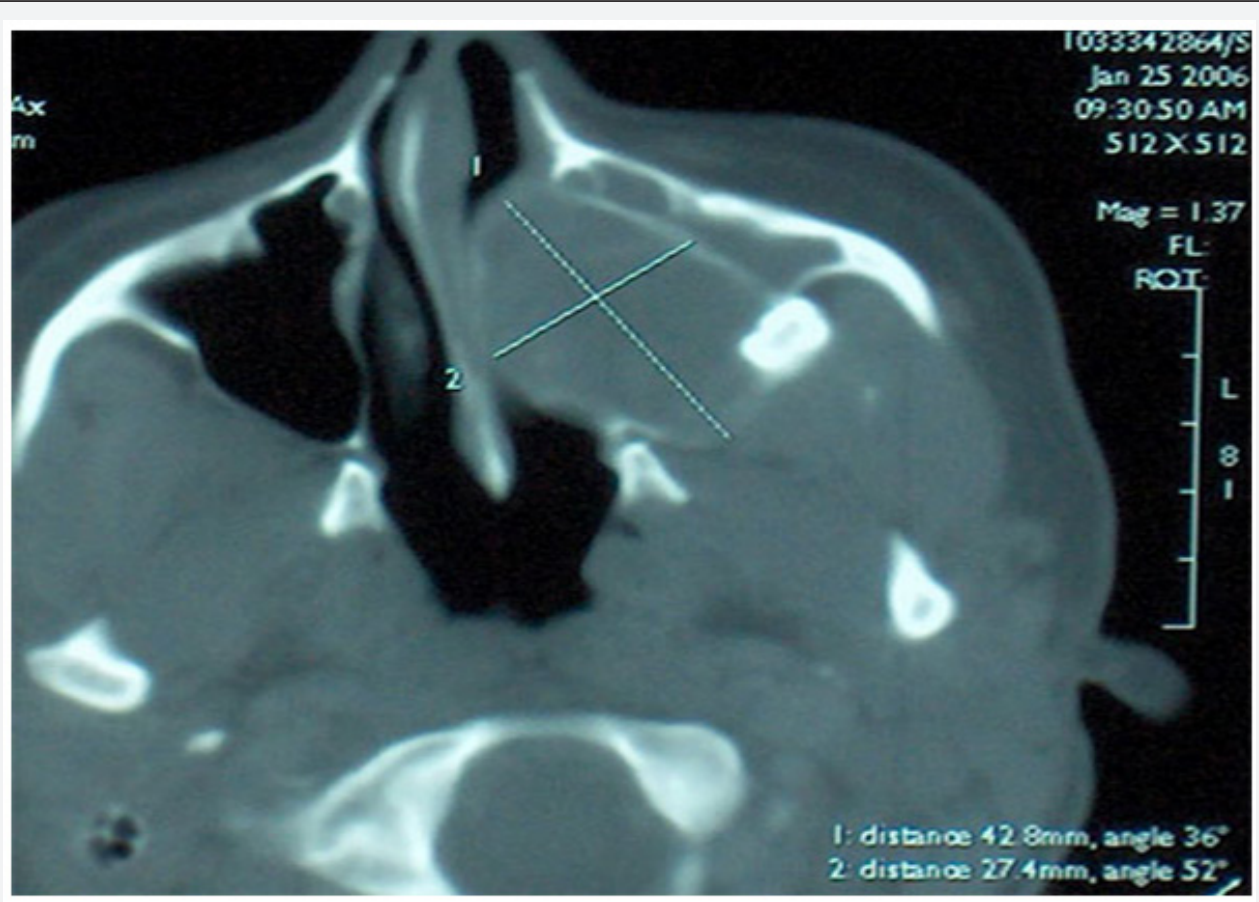

Figure 2: Axial computed tomographic scan showing a well defined opaque mass of left maxillary sinus and deviation of the nasal septum

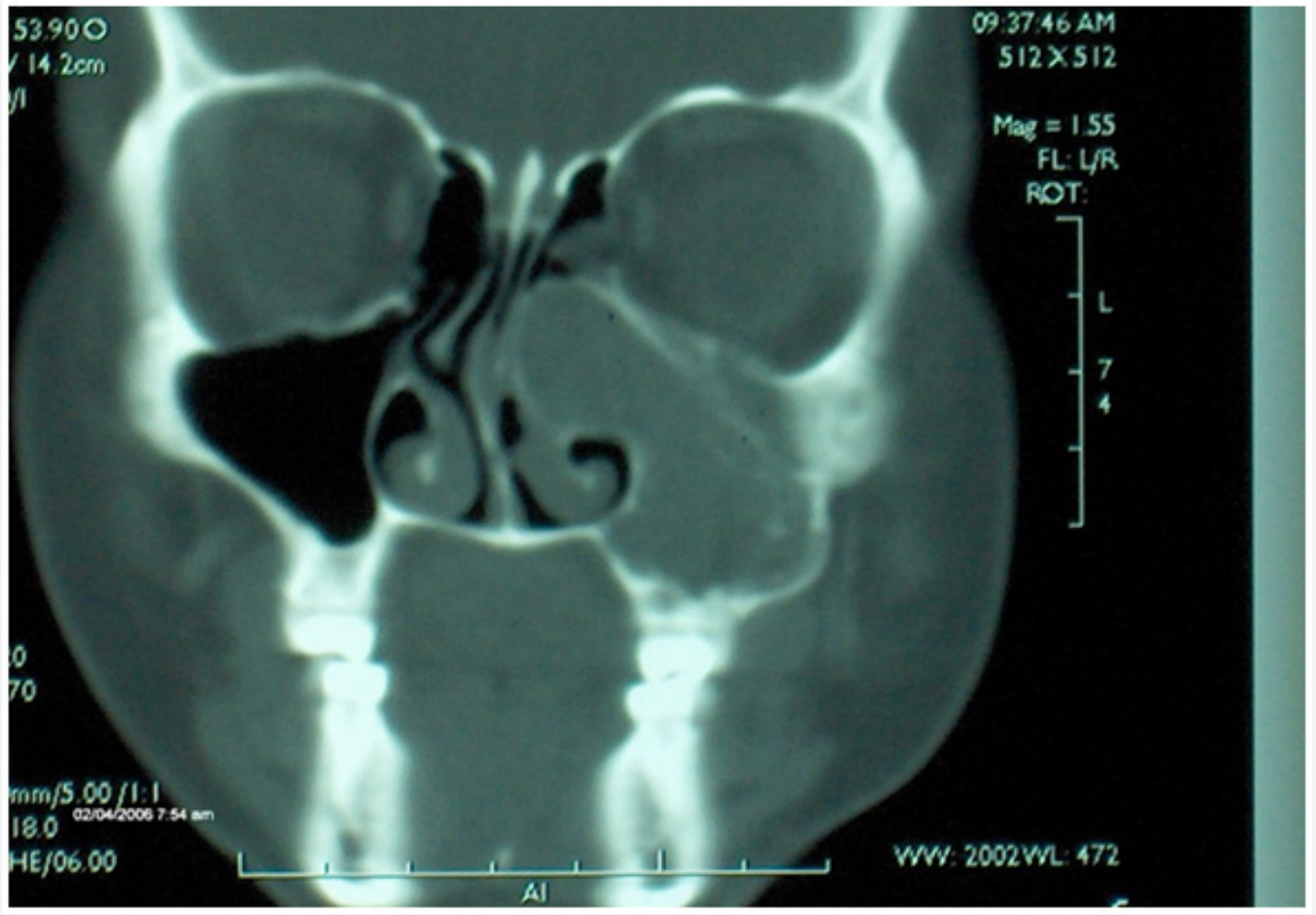

Figure 3: Coronal computed tomographic scan showing maxillary sinus walls with deviated nasal septum.

Incisional biopsy was done under local anesthesia for histopathological examination. Microscopically, the lesion showed strands and buds of epithelial cells in a very cellular connective tissue stroma (Figures $4 \& 5$ ). The cells composing the strands of epithelium are cuboidal to columnar with presence of stellate reticulum. The microscopic findings were consistent with the diagnosis of ameloblastic fibroma 


\section{Advances in Dentistry \& Oral Health}

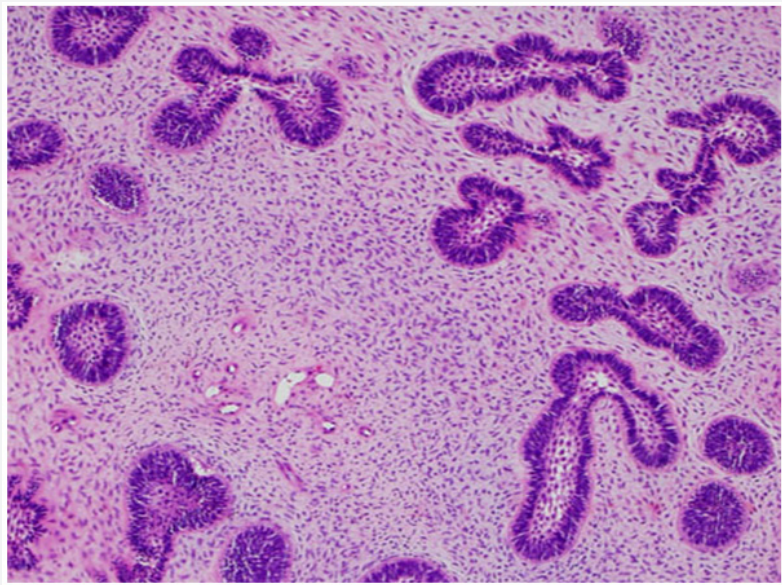

Figure 4: Low power magnification showing strands and buds of epithelial cells in very cellular connective tissue stroma.

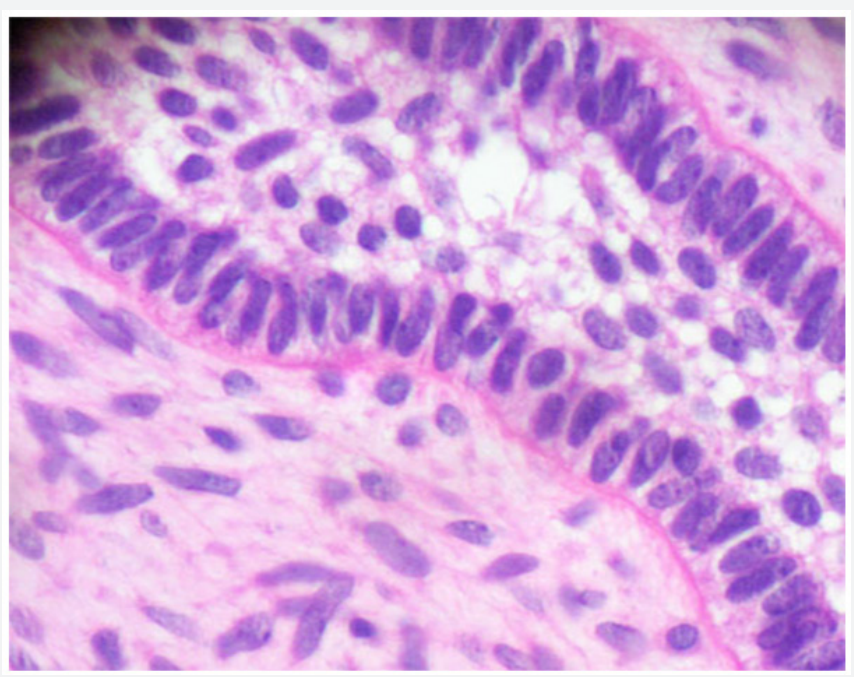

Figure 5: Higher magnification showing the epithelium which consists of ameloblast -like columnar cells surrounding others resembling stellate reticulum and connective tissue resembling the undifferentiated mesenchyme of the dental papilla.

Ten days later, excision of entire tumor was done under general the associated odontomes and displaced tooth \# 28 (Figures 6 \& anesthesia via intra-oral approach and through antrostomy. The tumor was excised by blunt dissection and curettage along with 7).

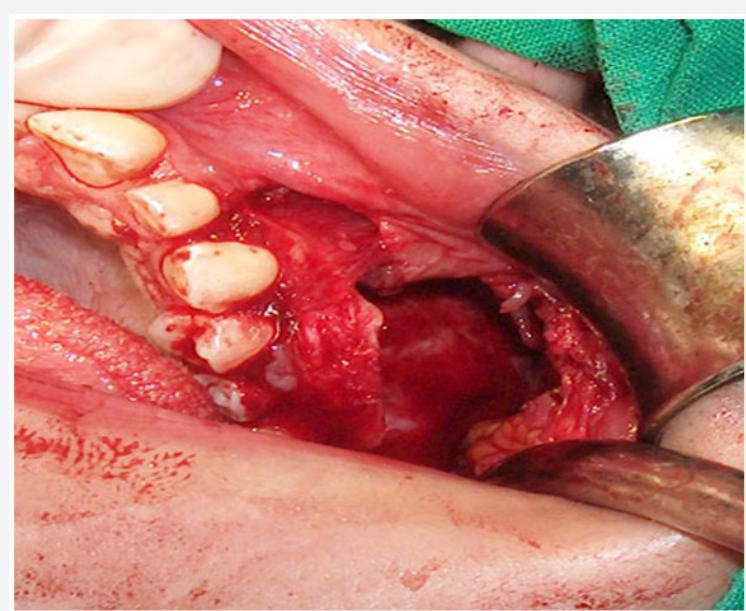

Figure 6: Showing intra-oral approach and antrostomy performed to excise the tumor. 


\section{Advances in Dentistry \& Oral Health}

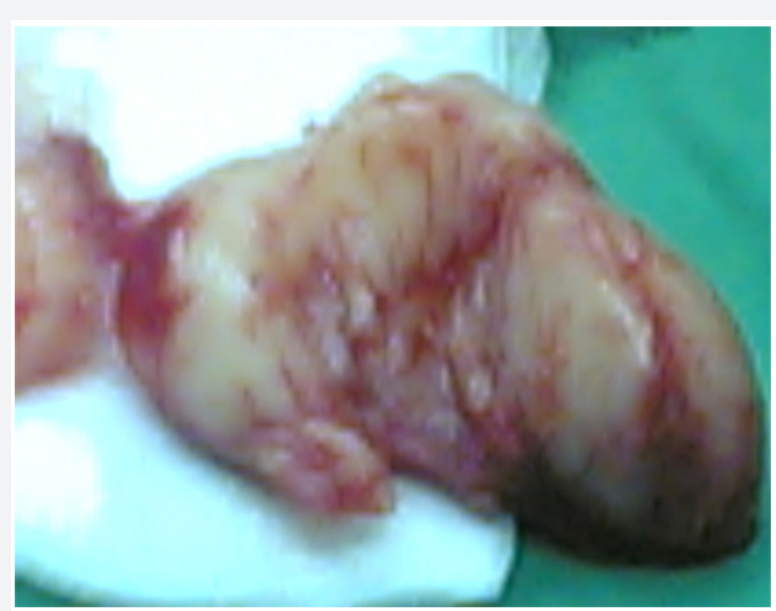

Figure 7: showing the excised well encapsulated mass.

The patient was followed up every three months for more than Tooth \# 26 was deemed non-vital and was root treated (Figures two years without any evidence of residual tumor or recurrence. $8 \& 9$ ).

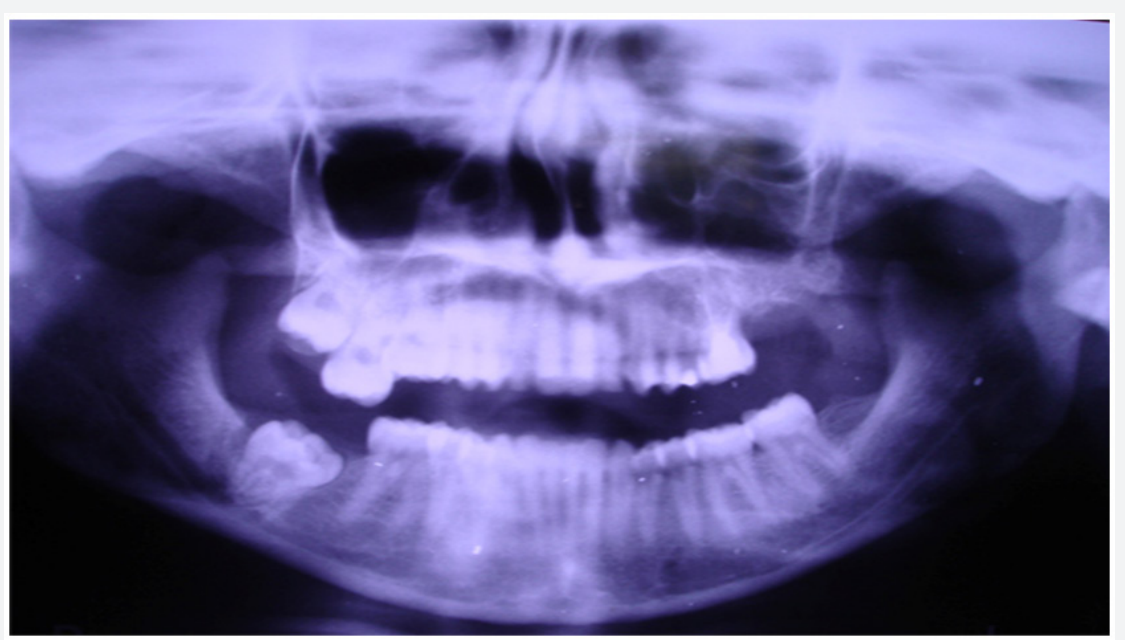

Figure 8: Orthopantomogram two years postoperatively showing bony healing of left maxilla and maxillary sins with the endodontically treated tooth \# 26.

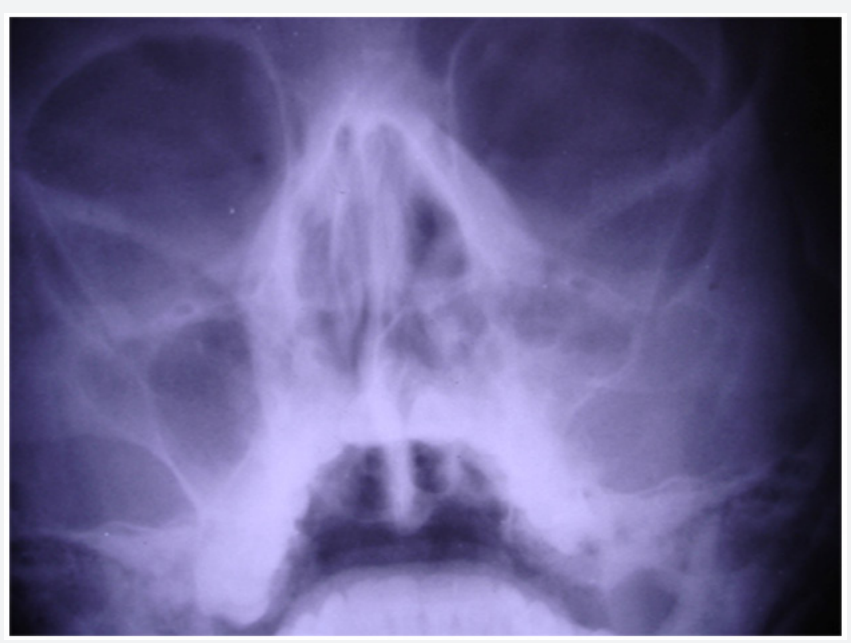

Figure 9: Occipitomental view: shows the healing of left maxillary sinus. 


\section{Discussion}

Ameloblastic Fibroma is a mixed tumor. It consists of odontogenic ectomesenchyme resembling the dental papilla and epithelium resembling dental lamina and enamel organ without dental hard tissues [9]. It is slow growing tumor which can cause bone expansion [10]. The treatment of A.F is controversial. Some authors recommend wide excision of the tumor unless the extent of surgery will result in significant deformity, [11] On the other hand, others support enucleation or curettage initially; with reserving modified block resection in cases of recurrence $[3,6,12]$.

In this case, enucleation and curettage were performed as a conservative treatment, with complete excision involving entire tumor, involved tooth and odontomes. The recurrence rate has been reported between 18.3 and 43.5\% [4,11]. Patient has been on follow up for two years without any clinical or radiographical sign of residual or recurrent disease. On orthopantomogram, sign of bone remodeling is obvious (Figure 8).

\section{References}

1. Kramer IR, Pindborg JJ, Shear M (1992) Histological typing of odontogenic tumors. WHO international Histological Classification of tumors Berlin. (2 ${ }^{\text {nd }}$ edn), Springer Verlag, Berlin, Germany, p. 122.

2. Harrison WS, Sordill WC, Sciubba DJ, Liebers RM (1982) Ameloblastic fibroma: management of a patient with an extensive tumor. Science Direct 104(4): 475- 477.
3. Bhaskar SN (1986) Synopsis of Oral Pathology. ( $7^{\text {th }}$ edn), Mosby St Louis MO, USA.

4. Trodahl JN (1972) Ameloblastic fibroma- a survey of cases from the Armed Forces Institute of Pathology. Oral Surg Oral Med Oral Pathol 33(4): 547- 558.

5. Ronald A, Schaffner DL, Myers DR (1982) Ameloblastic fibroma: a case report. Pediat Dentistry 4(3): 251-254.

6. Gorlin RJ, Chaudhry AP, Pindborg JJ (1961) Odontogenic tumors. Classification, histopathology, and clinical behavior in man and domesticated animals. Cancer 14(1): 73-101.

7. WB Saunders Shafer WG, Hine MR, Levy BM (1983) A textbook of oral pathology. Philadelphia, USA, pp. 552- 559.

8. Pereira KD, Bennett KM, Elkins TP, Qu Z (2004) Ameloblastic fibroma of the maxillary sinus. Int J Pediatr Otorhinolaryngol 68(11): 1473-1477.

9. Slootweg PJ (2005) Pathology and genetics of head and neck tumours. Ameloblastic fibroma/fibrodentinoma. In: Barnes L, Eveson JW, Reichart P, Sidransky D (Eds.), World Health Organisation classification of tumours. ( $9^{\text {th }}$ edn), Lyon: IARC Press, France, p. 9.

10. Y Takeda (1999) Ameloblastic fibroma and related lesions: current pathologic concept. Oral Oncol 35(6): 535-540.

11. Zallen RD, Preskar MH, McClary SA (1982) Ameloblastic fibroma. J Oral Maxillofac Surgery 40(8): 513-517.

12. EL Mosby, D Russel, S Noren, BF Barker (1998) Ameloblastic fibroma in a 7-week-old infant: a case report and review of the literature. J Oral Maxillofac Surgery 56(3): 368-372.

\section{Your next submission with Juniper Publishers} will reach you the below assets

- Quality Editorial service

- Swift Peer Review

- Reprints availability

- E-prints Service

- Manuscript Podcast for convenient understanding

- Global attainment for your research

- Manuscript accessibility in different formats

( Pdf, E-pub, Full Text, Audio)

- Unceasing customer service

Track the below URL for one-step submission https://juniperpublishers.com/online-submission.php 